\title{
Sistem Klasifikasi dalam Pemutaran Film: Studi Kasus Klasifikasi Film di Kinoki
}

\author{
Irham Nur Anshari
}

\begin{abstract}
This article concerns with the background, implementation, public acceptance and evaluation of the application of classification system as film regulation by Kinoki, an alternative screening space in Yogyakarta (2005-2011). The research adopted in this article is case studies. From the studies it is seen that the implementation of classification system at Kinoki is an effort to protect film viewers, while the application itself is more as a guideline for the viewers, yet so far public awareness and acceptance to this system is limited.
\end{abstract}

\section{Keywords:}

film; regulation; classification system; cencorship.

\begin{abstract}
Abstrak
Artikel ini menaruh perhatian pada latar belakang, implementasi, penerimaan publik dan evaluasi dari aplikasi sistem klasifikasi sebagai regulasi film oleh Kinoki, sebuah ruang pemutaran alternatif di Yogyakarta (2005-2011). Penelitian dalam artikel ini menggunakan studi kasus. Dari hasil penelitian ditemukan bahwa implementasi sistem klasifikasi di Kinoki berusaha melindungi penonton dengan meletakkan sistem sebatas panduan. Praktiknya perhatian dan penerimaan publik pada sistem ini masih terbatas.
\end{abstract}

\section{Kata Kunci:}

film; regulasi; sistem klasifikasi; sensor.

\section{Pendahuluan}

Film adalah salah satu media yang paling penting untuk dikaji dalam ilmu komunikasi maupun ilmu sosial lainnya. Kajian film tidak lagi sekadar dimaknai sebagai karya seni, tetapi lebih sebagai praktik sosial ataupun komunikasi massa. Jowett \& Linton menyebutkan bahwa film sebagai salah satu media massa, mampu merefleksikan masyarakat karena ia didesak oleh hakikat komersialnya untuk menyajikan isi yang tingkatnya akan menjamin kemungkinan
penonton(Jowett \& Linton, 1980: 74). Sedangkan Graeme Turner menyebut perspektif yang dominan dalam seluruh studi tentang hubungan film dan masyarakat sebagai pandangan yang relefksionis. Film dilihat sebagai cermin yang memantulkan kepercayaan-kepercayaan dan nilai-nilai dominan dalam kebudayaan (Turner, 1991: 131).

Garin Nugroho menuliskan bahwa film memang tak bisa lepas dari induk semangnya, kota dan pertumbuhannya. Ketika lembaga

\footnotetext{
- Alumni Jurusan Ilmu Komunikasi UGM

Email: rikirham@yahoo.com
} 
keluarga tidak sanggup lagi menjadi sistem nilai utama dan satu-satunya, berbagai lembaga dilahirkan sebagai mekanisme baru dalam peranan seperti yang dikatakan Herbert Spencer, sebagai organ-organ yang menjalankan fungsi dalam masyarakat (Nugroho, 1995: 147). Pernyataan tersebut menggarisbawahi alasan sensor film muncul. Persoalan awalnya adalah persoalan kontrol ideologi dan budaya.

Namun seiring perkembangan, fungsi sensor mulai menemui peran-peran baru. Sejarah panjang sensor di Indonesia, sejak munculnya Staatsblad Van Nederlandsch Indi pada masa Hindia Belanda, telah menuai banyak persoalan. Dalam Menguak Peta Perfilman Indonesia (Irawanto dkk, 2004: 74-75) disimpulkan beberapa hal pokok terkait penyelenggaraan sensor antara lain: menghambat kebebasan berekspresi dan mendapatkan informasi, kriteria sensor yang ambigu, generalisasi sensor yang tidak menghargai kepentingan apresiasi film, peran pemerintah yang menjadikan sensor sebagai upaya menjaga status quo, dan sebagainya.

Sebagai alternatif sensor di Indonesia, pada 2007, beberapa pihak perfilman yang menamakan kelompok mereka Masyarakat Film Indonesia (MFI) menawarkan sistem klasifikasi. ${ }^{1}$ Isi tawaran itu adalah dalam pelaksanaan fungsi Lembaga Sensor Film (LSF), sistem pemberdayaan dapat dilakukan melalui penilaian klasifikasi film (rating), sehingga semua unsur harus berperan, tak hanya yang berkiprah di industri, namun justru yang utama adalah peran keluarga, sebagai kunci utama pemberdayaan publik, dan sektor pendidikan. Sebagai pagar untuk melindungi film dari eksploitasi tampilan pornografi dan kekerasan, bisa diakomodasi dalam penilaian "un-rated", yaitu ditolak sama sekali. Sebaliknya, perlu perlakuan khusus untuk film-film yang keseluruhannya dibuat

\footnotetext{
1 Risalah Sidang Perkara Nomor 29/PUU-V/2007.
} Hlm. 17. dengan sengaja untuk festival, pendidikan, instruksional, atau kesehatan.

Bersamaan dengan tuntutan MFI, penulis mengamati wacana umum yang mengemuka ke publik, menyatakan bahwa sistem klasifikasi film kerap dianggap sebagai metode yang paling konstitusional, jika dibandingkan dengan penyensoran. Hal itu dikarenakan sistem klasifikasi tidak memberikan batasan akan kebebasan berpendapat dan berekspresi, melainkan menetapkan pengelompokan penonton yang didasarkan atas usia.

Namun, sistem klasifikasi ini pada akhirnya tidak disetujui oleh Mahkamah Konstitusi. ${ }^{2}$ Alasannya, sistem klasifikasi film adalah sistem yang diberlakukan pada suatu film atas dasar kelompok umur penonton film. Film hanya akan diedarkan pada kelompok terbatas, seperti hanya untuk orang dewasa, anak-anak, atau anak-anak dengan pengawasan orang dewasa.

Di negara-negara yang menganut sistem liberal, klasifikasi film dianggap sebagai metode yang paling konstitusional, jika dibandingkan dengan sistem sensor, karena sistem klasifikasi tidak membatasi kebebasan berpendapat dan berekspresi. Akan tetapi, sistem ini lemah dalam implementasinya.

Pengategorian "adults only" (khusus dewasa) justru akan mengundang minat kelompok umur yang belum dewasa, sehingga menjadi publikasi gratis untuk menarik keingintahuan anak-anak. Selain itu, klasifikasi film juga tidak selalu bisa menjamin konsistensi dalam penerapannya. Kecenderungan yang mungkin timbul adalah pengusaha bioskop tidak peduli dan tidak tegas menolak penonton di luar kategori film yang ditayangkan, karena orientasinya adalah kepentingan bisnis. Dengan demikian, sistem ini dianggap tidak sepenuhnya mampu melindungi kelompok anak-anak.

Di tengah perdebatan regulasi sensor, yang dianggap mengekang kebebasan

2Ibid., 51-52 
Tabel. 1

Jumlah Penonton Kinoki (Mei-Juli 2010)

\begin{tabular}{|c|c|c|c|c|}
\hline No & Tanggal & Judul Film & $\begin{array}{l}\text { Batasan } \\
\text { Umur }\end{array}$ & $\begin{array}{l}\text { Jumlah } \\
\text { Penonton }\end{array}$ \\
\hline 1 & 4 Mei 2010 & Salvador Allende & $18+$ & 20 \\
\hline 2 & 8 Mei 2010 & At the Very Bottom of Everything & $17+$ & 48 \\
\hline 3 & 11 Mei 2010 & Moloch & $21+$ & 15 \\
\hline 4 & 13 Mei 2010 & Maradona & $18+$ & 18 \\
\hline 5 & 18 Mei 2010 & $\begin{array}{l}\text { Atlantis, Kompilasi Film Perempuan dan Syariat } \\
\text { Islam (Mode, Bunga, Dalam Pandanganku) }\end{array}$ & $18+$ & 25 \\
\hline 6 & 25 Mei 2010 & Head On & $21+$ & 20 \\
\hline 7 & 27 Mei 2010 & La Sociologie est un sport de combat & $18+$ & 21 \\
\hline 8 & 1 Juni 2010 & Still Walking & $15+$ & 7 \\
\hline 9 & 8 Juni 2010 & $\begin{array}{l}\text { Kita tidak Benar-benar Bicara, Bank Memory, } \\
\text { Staratelj, Layang-layang Ayah Bunda, Tiga Hari untuk } \\
\text { Sementara }\end{array}$ & $15+$ & 26 \\
\hline 10 & 10 Juni 2010 & Air Doll & $18+$ & 11 \\
\hline 11 & 15 Juni 2010 & Afterlife & $15+$ & 12 \\
\hline 12 & 16 Juni 2010 & $\begin{array}{l}\text { Kompilasi Film Pendek (Limang Libo, Hujan tak jadi } \\
\text { Datang, The Outing, Focal Point) }\end{array}$ & $15+$ & 10 \\
\hline 13 & 16 Juni 2010 & The Nursery & $15+$ & 8 \\
\hline 14 & 17 Juni 2010 & This Longging & $15+$ & 8 \\
\hline 15 & 17 Juni 2010 & Babi Buta yang ingin Terbang & $18+$ & 18 \\
\hline 16 & 22 Juni 2010 & $\begin{array}{l}\text { Pemutaran Film-Film pendek karya peserta } \\
\text { "Berlinale Talent Campus" (Awra Amba, Dry Rain, } \\
\text { Parkish The Travelling Cinema) }\end{array}$ & $15+$ & 21 \\
\hline 17 & 24 Juni 2010 & Maboroshi & $18+$ & 22 \\
\hline 18 & 29 Juni 2010 & Nobody Knows & $15+$ & 16 \\
\hline 19 & 6 Juli 2010 & Soylent Green & $15+$ & 9 \\
\hline 20 & 13 Juli 2010 & RRRrrr... & $15+$ & 9 \\
\hline 21 & 15 Juli 2010 & Children of Men & $15+$ & 13 \\
\hline 22 & 20 Juli 2010 & Last Night & $15+$ & 9 \\
\hline 23 & 22 Juli 2010 & $5 \times 2$ & $15+$ & 11 \\
\hline 24 & 27 Juli 2010 & $\begin{array}{l}\text { Girls, Time According to Theijs, Wow!Vanessa - The } \\
\text { Big Jump }\end{array}$ & $\begin{array}{l}\text { Semua } \\
\text { Umur }\end{array}$ & 13 \\
\hline 25 & 29 Juli 2010 & The Road & $15+$ & 10 \\
\hline
\end{tabular}

Sumber: Hasil wawancara dan studi dokumentasi

berekspresi dan menerima informasi, beberapa ruang pemutaran alternatif mencoba memberi tawaran baru. Setidaknya pada saat penelitian ini dilakukan (2010), terdapat beberapa ruang pemutaran alternatif antara lain: Kinoki dan Lembaga Indonesia Perancis (LIP) di Yogyakarta, Kineruku di Bandung, dan Kineforum Dewan Kesenian Jakarta. Tempattempat tersebut menjadi wadah distribusi film-film lokal, regional, maupun internasional yang ditolak bioskop komersial ataupun yang memang menolak untuk memutarkan filmnya di sana.

Sebagai alternatif sensor, ruang-ruang pemutaran alternatif tersebut membuat aturannya masing-masing. Kinoki contohnya, salah satu tempat pemutaran alternatif di Yogyakarta yang aktif di tahun 2005-2011, memilih untuk menggunakan sistem klasifikasi. Ini menjadi semacam uji coba bagaimana bila 
sistem klasifikasi diterapkan di Indonesia. Kinoki menjadi representatif selain bioskop komersial karena meski merupakan ruang pemutaran alternatif, Kinoki mempunyai audiens yang tidak sedikit dibanding ruang pemutaran film lain dan dalam skala umur dari anak kecil hingga dewasa.

Kinoki akhirnya berkembang menjadi ruang bertemunya orang-orang yang terlibat dalam dunia film, banyak diselenggarakan diskusi seputar perfilman Indonesia di sini. Kinoki sempat dipercaya sebagai tempat distribusi film-film yang tidak mampu dipertontonkan di bioskop komersil. Kerap pula dijadikan venue beberapa festival film di Yogyakarta.

Meneliti sistem klasifikasi yang telah diterapkan Kinoki adalah langkah untuk membaca aplikasi penerapan sistem ini di Indonesia, karena hingga kini sistem klasifikasi belum bisa diterapkan untuk menggantikan regulasi sensor, meski berbagai negara telah menerapkannya. Tulisan ini mempertanyakan apakah sistem tersebut, sebagai aturan pemutaran film, memang lebih mampu mengakomodasi seluruh kepentingan publik. Harapannya tulisan ini tidak sekadar mengetahui dampak dari sistem klasifikasi, positif atau justru memunculkan masalah sosial yang lebih besar dari sensor. Namun juga dapat membuka wacana baru tentang regulasi film di Indonesia.

Berdasarkan permasalahan itu, penulis merumuskan tiga masalah penelitian. Pertama, bagaimana proses pembuatan keputusan Kinoki untuk menerapkan sistem klasifikasi film? Kedua, bagaimana bekerjanya sistem klasifikasi film di Kinoki? Ketiga, bagaimana penerimaan publik atas sistem klasifikasi film di Kinoki?

Mengacu pada data yang hendak diperoleh, metode penelitian yang digunakan adalah kualitatif menggunakan studi kasus. Penelitian ini memusatkan diri secara intensif pada satu objek tertentu yang mempelajarinya sebagai suatu kasus, objek tersebutadalah sistem klasifikasi film di Kinoki. Pengumpulan data dilakukan dengan tiga cara. Pertama, observasi yang dilakukan penulis di Kinoki selama bulan Mei-Juli 2010. Penulis menghadiri program pemutaran yang dilakukan Kinoki selama masa penelitian, observasi difokuskan untuk memeriksa praktik dari sistem klasifikasi.

Kedua, penulis mempelajari dokumentasi Kinoki baik berupa foto, proposal, maupun laporan kegiatan untuk melacak proses yang dilalui Kinoki dalam menerapkan sistem tersebut. Ketiga, wawancara yang dilakukan pada pihak manajemen Kinoki, pembuat film yang diputar di Kinoki, serta penonton film di Kinoki, khususnya pertanyaan tentang penerimaan publik.

Penulis melakukan wawancara mendalam pada penanggung jawab Kinoki, Elida Tamalagi ${ }^{3}$. Penulis mewawancarai tiga sutradara yang filmnya pernah diputar di Kinoki sebagai representasi pembuat film. Sedangkan sebagai perwakilan penonton, penulis memilih 10 orang dengan intensitas menonton yang tinggi, yaitu hadir dalam minimal tiga kali pemutaran, dan 10 orang dengan intensitas menonton rendah, yaitu pernah datang kurang dari tiga kali pemutaran. Tulisan ini merupakan ringkasan dari penelitian yang dilakukan penulis pada tahun 2010. Adapun ketika tulisan ini dibuat, Kinoki sudah tidak aktif dan wacana sistem klasifikasi seperti hilang di ruang-ruang pemutaran alternatif.

\section{Latar Belakang Sistem Klasifikasi Kinoki}

Meletakkan film pada konteks sosial, politik, dan budaya dalam proses komunikasi yang sedang berlangsung, sama artinya dengan memahami preferensi penonton

\footnotetext{
3 Penanggung jawab Kinoki, Patricia Elida Tamalagi (lebih sering disebut Elida Tamalagi) meninggal pada 13 September 2011. Meski penulis belum pernah mendengar kabar non-aktifnya Kinoki secara resmi, namun sejak meninggalnya Tamalagi penulis tidak pernah mengetahui masih ada atau tidak aktivitas di bawah nama Kinoki.
} 
yang pada gilirannya menciptakan citra penonton film (Irawanto, 1999: 11). Ketika film sudah melibatkan masyarakat dan identitas sebuah bangsa, film kemudian dipaksa masuk dalam kebijakan politik. Sejarah di Indonesia menunjukkan bahwa perfilman baik dalam konteks industri hiburan ataupun karya seni akhirnya sangat tergantung pada sistem pemerintahan yang ada (Lihat Biran, 1993 dan Arief dkk., 1997).

Namun, tujuan dibuatnya regulasi film menjadi rancu. Sungguh-sungguh menjaga identitas bangsa, yang berarti menjaga status quo pemerintahan atau tidak. Kebijakan sensor pertama kali muncul di Indonesia untuk melindungi citra orang Belanda di mata pribumi. Perilaku orang Barat (Amerika Serikat dan Eropa) yang diilustrasikan dalam film sebagai orang yang menonjolkan kekerasan dan kekejaman dalam menyelesaikan masalah, tema seks yang cukup menonjol, ditambah lagi mempertontonkan adegan seks di luar nikah mendorong pemerintah kolonial pada masa itu untuk melakukan sensor (Arief dkk, 1997: 57). Meski kebanyakan minat penduduk pribumi untuk menonton film lebih tertuju pada visualisasi dan bukan alur cerita, penggambaran itu tetap saja merisaukan sejumlah tokoh pemerintahan Belanda (Arief dkk, 1997: 55).

Muncul desakan untuk membuat regulasi dari perspektif pembuat film. Sensor dicap sebagai antitesis dari konsep kebebasan berbicara (freedom of speech) dan berekspresi. Menurut Robert A. Dahl, hal ini dikarenakan sistem demokrasi bertujuan untuk menawarkan pilihan kepada masyarakat. Jadi, pengekangan terhadap munculnya ide-ide baru sama halnya dengan membatasi pilihan itu (Dahl, 2001: 34).

Miriam Budiardjo menyepakati bahwa salah satu lembaga yang perlu diselenggarakan dalam melaksanakan nilai-nilai demokrasi ialah pers dan media massa. Dalam konteks ini film didefinisikan sebagai media massa, yang bebas untuk menyatakan pendapat (Budiardjo, 1991: 61).

\section{Kinoki dan Kebijakan Pemutaran Film dari Perspektif Penonton}

Elida Tamalagi, penanggung jawab Kinoki sejak awal dibentuk, menjelaskan bahwa pada awal berdirinya, tahun 2005, Kinoki sebenarnya telah memikirkan aturan pemutaran. Namun saat itu belum bisa langsung memutuskan bentuk aturan pemutaran yang sesuai, mengingat pada masa itu masih diperlukan pembacaan terhadap kebutuhan penonton. Acuannya adalah kebebasan dan perlindungan untuk menerima informasi. Sama sekali tidak ada pemikiran mengenai penjagaan identitas bangsa ataupun kebebasan menyampaikan ekspresi dari perspektif pembuat film. ${ }^{4}$

Untuk menjadikan perspektif penonton sebagai suara penting, Kinoki melakukan upaya penyatuan perspektif antara pembuat film dengan penonton di Indonesia. Artinya apabila sebuah sistem pemutaran muncul, akan ada dasar yang kuat yaitu kebutuhan publik. Publik di sini adalah penonton film, baik itu penonton di bioskop komersial ataupun ruang pemutaran lain. ${ }^{5}$

Screening Hall On Kinoki (SHOK) adalah strategi Kinoki untuk mendekatkan diri kepada pembuat film. Hal ini dilakukan karena mengingat di masa awal berdirinya, Kinoki seolah memainkan peran antagonis di mata pembuat film. Dalam SHOK, Kinoki memosisikan pembuat film sebagai programer, menyiapkan film dan menentukan target penonton. ${ }^{6}$ Dari SHOK itulah perlahan suara

\footnotetext{
4 Wawancara dilakukan pada tanggal 23 Juni 2010 dan 7 Oktober 2010. Untuk selanjutnya, referensi wawancara dengan Tamalagi merujuk pada wawancara pada dua tanggal ini. Peneliti memilih untuk tidak merujuk wawancara pada salah satu tanggal dari dua tanggal tersebut.

5 Ibid.

6 "SHOK" dalam Laporan Kegiatan Kinoki. Terdapat keterangan yang kurang pasti mengenai awal mula kegiatan itu dilaksanakan. Namun berdasarkan temuan
} 
mulai solid, pembuat film mulai memiliki perspektif penonton.

Penonton menjadi raja. Bagi penonton yang antusias terhadap film, SHOK menjadi even yang sangat fun. Terlebih jika even dibungkus secara tematik dan disertai pesta. Tamalagi memberikan contoh, "Saat pemutaran film Rockabilly Weekender, orang-orang datang memakai kostum Rockabilly. Begitu pun saat Nightmare Before Christmas diputar. Mereka juga benar-benar menyanyi saat kami memutar film yang isinya membuat penonton ingin bernyanyi. Hal-hal seperti itu yang menyenangkan".

Saat itulah Kinoki melihat perlunya pemetaan publik sebagai pertimbangan aturan pemutaran. Hasilnya menunjukkan dua jenis penonton. Pertama, penonton aktif, yaitu penonton yang datang dengan kesiapan menonton. Penonton ini biasanya telah mengakses informasi mengenai film yang akan ditonton. Kedua, penonton pasif, yaitu penonton yang datang untuk menonton film tanpa persiapan sebelumnya. Penonton di Kinoki lebih banyak merupakan penonton aktif. Sedangkan penonton pasif cenderung muncul ketika Kinoki melakukan pemutaran di venue lain, seperti layar tancap. ${ }^{7}$

Setelah dua tahun aktif, Kinokimenerapkan kebijakan pemutaran dengan mengedepankan dialog. Tujuannya untuk mengakomodir kebutuhan penonton aktif maupun pasif. Misalnya ketika penonton membawa anaknya pada pemutaran film dengan konten seks atau kekerasan, pihak Kinoki akan berdialog untuk menginformasikan hal itu. ${ }^{8}$ Dialog tersebut sesungguhnya untuk mengingatkan orang tua tentang adegan-adegan yang sebaiknya tidak ditonton anak kecil. Selain itu juga untuk menghimbau orang tua agar mendampingi anaknya saat menonton sehingga dapat

data, kegiatan ini dilaksanakan sekitar tahun 2006.

7 "SHOK" dalam Laporan Kegiatan Kinoki.

8 "Sinema Anak" dalam Laporan Kegiatan Kinoki. mengawasi dan menjelaskan mengenai adeganadegan tersebut.

Sistem klasifikasi ini resmi dipublikasikan di Taman Budaya Yogyakarta, ketika ruang pemutaran alternatif ini berubah menjadi Kinoki "Pusat Data. Pemutaran. Pendidikan Populer". Tetapi sebenarnya sistem klasifikasi "non formal" sudah dilakukan sejak tahun-tahun awal Kinoki berdiri. Contohnya saat memutar film ada film yang banyak adegan seks, pintu akan ditutup karena posisi layar terlihat dari pinggir jalan. Orang yang ingin menonton harus masuk, sehingga memungkinkan untuk berdialog atau memberikan informasi dari awal mengenai adegan di film. ${ }^{9}$

Pada akhir 2007, wacana sistem klasifikasi mulai muncul di Indonesia, dirumuskan oleh MFI. Wacana tersebut tidak otomatis menjadi perhatian Kinoki, mengingat kebijakan pemutaran yang telah dilakukan sejak sebelumnya tidak menimbulkan masalah besar antara Kinoki dengan penonton. Sistem itu diperkenalkan pada Kinoki untuk dipraktikkan. Pada acara eventual, Mari Menonton 2008, Kinoki mencoba mempraktikkan sistem itu dalam program film-film uji coba klasifikasi dan dirangkum dalam seminar.

Salah satu upaya mematangkan praktik sistem itu, Kinoki menggagas program "Mari Menonton" selama dua hari pada Juli 2008, di Gedung F Benteng Vredeburg. Focus Group Discussion (FGD) bertema "Klasifikasi Cara Saya" adalah bagian dari rangkaian diskusi MFI dengan banyak pihak yang berkaitan dengan klasifikasi. Diskusi ini mengundang lima dosen psikologi perkembangan anak dan sosial dari berbagai universitas di Yogyakarta.

Lima dosen tersebut adalah Prof. Dr. Endang Ekowarni dan Drs. Fauzan Heru Santhoso dari Universitas Gadjah Mada, Rina Mulyati, S.Psi., M.Si dari Universitas Islam Indonesia, Yohannes Babtista Cahya Widianto S.Psi., dari Sanata Darma, dan Hady Suyono S,Psi., M.Si. dari

${ }^{9}$ Ibid. 
Universitas Ahmad Dahlan. Sedangkan dari pihak MFI diwakili oleh Lisabona Rahman, Tito Imanda, dan Alex Sihar. ${ }^{10}$

Kinoki pernah pula mengadakan seminar klasifikasi. Seminar dihadiri perwakilan MFI dan mendatangkan para psikolog. Beberapa contoh film dibahas dalam seminar. Ternyata, yang menjadi perdebatan bukan hanya film yang menampilkan pornografi tetapi juga film cerita tentang anak-anak, dengan tokoh anakanak namun audionya dinilai meneror dan mengandung kekerasan. Hal tersebut menjadi masukan penting, karena ketika berbicara tentang penonton kelompok anak-anak, yang perlu diperhatikan tak hanya urusan pornografi. Perlindungan terhadap penonton tidak sesederhana itu.

Pun mengenai jenis kelamin tokoh dalam tayangan. Contohnya tokoh Ableh di Unyil yang masih samar jenis kelaminnya. Suaranya pun tidak bisa dikategorikan maskulin atau feminin. Namun pemerintah kurang kritis sehingga hal itu dianggap tidak masalah jika ditonton anak-anak. Padahal kemungkinan mereka akan bertanya tokoh dengan figur lelaki namun berambut panjang tersebut sesungguhnya laki-laki atau perempuan. Untuk diketahui, sutradara Unyil adalah seorang waria, ia sengaja menciptakan Ableh sebagai tokoh abu-abu. ${ }^{11}$

Hasil uji coba dari program klasifikasi film dan seminar menjadi bahan pertimbangan Kinoki untuk memikirkan kebijakan pemutaran, dengan perspektif yang lebih luas. Menurut Tamalagi, kebutuhan penonton tetap menjadi dasar kebijakan, namun Kinoki juga mempertimbangkan untuk meningkatkan pengetahuan penonton tentang film. Klasifikasi ini dianggap sebagai langkah baru, yaitu kebijakan untuk melindungi penonton dengan sebuah sistem perkembangan pendidikan.

\footnotetext{
10 "Proteksi dengan klasifikasi" dalam Laporan Kegiatan Kinoki.

11 “Sinema Anak" dalam Laporan Kegiatan Kinoki.
}

\section{Masyarakat Film Indonesia dan Sistem Klasifikasi}

Pada 3 Januari 2007, berkumpul 202 orang mewakili pekerja film aktif. Secara aklamasi, pertemuan diadakan dalam rangka membentuk suatu gerakan bernama Masyarakat film Indonesia (MFI). Gerakan ini didukung secara individual oleh orang-orang yang bekerja di bidang perfilman, yang sekaligus menjadi anggota. ${ }^{12}$

Salah satu wacana yang dipikirkan MFI adalah sensor film. Lembaga Klasifikasi Film yang ditawarkan MFI berbentuk asosiasi profesional bagi pekerja film, yang bisa berfungsi dengan efektif dan mendukung dirinya sendiri. Pemerintah berperan sebagai fasilitator. ${ }^{13}$ Akhir 2007 MFI memperkenalkan rumusan draft hasil studi klasifikasi pada Kinoki untuk diaplikasikan. Menurut keterangan dari Tamalagi, Kinoki sebenarnya tidak mengikuti atau menyetujui kebijakan MFI. Kinoki sebatas turut mendukung.

Ketika Kinoki berubah menjadi Kinoki "Pusat Data. Pemutaran. Pendidikan Populer.", Kinoki mempublikasikan sistem klasifikasi, dalam konteks ini versi MFI. Publikasi dilakukan saat ada pemutaran film rutin di Taman Budaya Yogyakarta. Alasannya politis. Meski tidak menyetujui karena tidak terlibat langsung dalam perumusan draft hasil studi klasifikasi, namun Kinoki mendukung hal-hal yang diperjuangkan oleh MFI demi perkembangan dunia perfilman di Indonesia. ${ }^{14}$

Melihat konteks kebutuhan dan perlindungan penonton, Kinoki mendapati adanya perkembangan positif. Sistem klasifikasi film ternyata mengembangkan kecerdasan penonton untuk menelaah film dalam konteks. Kesadaran akan tanggung jawab dan edukasi

\footnotetext{
${ }^{12} \mathrm{http}: / /$ masyarakatfilmindonesia.wordpress. com/2007/04/27/apa-permasalahan-mendasarperfilman/ diakses pada 1 Oktober 2010.

${ }^{13} \mathrm{http}: / /$ masyarakatfilmindonesia.wordpress.com/ faq/ diakses pada 1 Oktober 2010

${ }^{14}$ Ibid.
} 
dari orang yang lebih tua ke yang lebih muda pun dapat terangsang. Sistem ini kemudian mulai rutin digunakan Kinoki. ${ }^{15}$

Kinoki merasa sistem klasifikasi film penting untuk diuji coba, mengingat perlunya mendefinisikan Kinoki sebagai ruang eksibisi. Sebagai langkah lanjutan dari ruang pemutaran alternatif yang berguna untuk pendidikan penonton. Meskipun pada masa awal penerapannya Kinoki menyadari bahwa penonton belum menyadari dan membutuhkan keberadaan sistem ini.

Mengingat adanya dua tipe penonton film, penonton aktif dan penonton pasif, Kinoki merasa perlu memosisikan lebih matang apakah sistem klasifikasi akan menjadi regulasi/ aturan atau panduan/ tuntunan. Sekali lagi berusaha memandang dari perspektif penonton, Kinoki menjadikan sistem klasifikasi sebagai panduan tetapi dengan penerapan yang ketat.

Sebagai ruang pemutaran, Kinoki akan lebih mengikuti regulasi apabila pemerintah memilih sistem klasifikasi dibanding sensor. Namun berbeda dengan sensor, sistem klasifikasi berarti menaruh tanggung jawab besar pada semua ruang pemutaran. Untuk itu Kinoki merasa perlu adanya ketegasan pemerintah yang diikuti dengan kesadaran pihak-pihak di ruang pemutaran baik itu bioskop komersil, ruang pemutaran alternatif, atau sejenisnya. ${ }^{16}$

MFI di satu sisi menawarkan adanya Lembaga Klasifikasi Film yang berbentuk Asosiasi Profesional bagi pekerja film. Ini berarti wadah independen yang bisa berfungsi dengan efektif dan mendukung dirinya sendiri. Sebagai ruang pemutaran Kinoki melihat tidak adanya keberatan apakah sistem klasifikasi itu akan ada di bawah tangan pemerintah atau badan independen. Di satu sisi ketika sebuah regulasi di bawah badan independen, regulasi tersebut akan lepas dari usaha-usaha

\footnotetext{
${ }^{15}$ Ibid.

${ }^{16} \mathrm{Ibid}$.
}

menjaga status quo. Namun di sisi lain, akan ada penyempitan kekuatan otoritas.

Patut dipertanyakan apakah semua ruang pemutaran film nantinya bisa tunduk pada MFI, badan independen yang otoritasnya tidak sekuat lembaga pemerintah. Kinoki lebih percaya bahwa sistem klasifikasi akan berjalan lancar jika badan dan majelis klasifikasi dibentuk oleh pemerintah. Artinya, pemerintah secara nyata bertanggung jawab, dengan mengatur badan itu melalui kebijakan.

\section{Pengklasifikasian Film}

Garin Nugroho (2005: 83), pernah menulis bahwa sistem klasifikasi selain memberikan kebebasan berpendapat dan berekspresi, dapat dianggap pula sebagai strategi budaya dan pendidikan. Misalnya pada kategorisasi batasan umur menonton yaitu 21, 17, dan 13 tahun. Pada kategorisasi ini, seluruh aspek strategi berbangsa, khususnya pendidikan etika, dipersiapkan untuk mengolah daya kritis warga negara. Pada umur 17 tahun misalnya, setiap warga negara dipersiapkan mendapat pendidikan seks serta kemampuan kritis untuk memilih, sesuai perkembangan dan tuntutan zaman.

Mengingat perannya sebagai strategi budaya dan pendidikan, klasifikasi sebuah film perlu dipikirkan secara jangka panjang dengan peninjauan berkala. Klasifikasi hakikatnya tidak bisa berdasar pada adegan per adegan dalam film saja, tetapi lebih jauh lagi, melihat konteks film secara keseluruhan. Kemudian diikuti peninjauan ulang di tingkat penerimaan penonton, yang dimungkinkan mengalami perubahan.

Kinoki sebagai ruang pemutaran memilih untuk memegang tanggung jawab penuh dalam mengklasifikasikan film. Seperti yang disampaikan Tamalagi selaku penanggung jawab Kinoki, klasifikasi harus melihat film sebagai konteks film utuh, berdasarkan pada penerimaan penonton.

Cara berpikir dengan melihat film secara keseluruhan, diterapkan oleh Kinoki sejak 
melakukan programming film. Programming dilakukan dengan menentukan film-film yang akan diputar tiap bulannya, yang kemudian menghasilkan klasifikasi film yang diputar di Kinoki. Tiap-tiap programmer di Kinoki menyiapkan klasifikasinya sendiri, lalu didiskusikan lagi kepastian batasan umurnya. Sedangkan landasannya didapat dengan mempelajari pasal-pasal lengkap klasifikasi film hasil studi MFI. Secara teknis, Kinoki juga mengikuti logo-logo batasan umur yang ada dalam draft hasil studi tersebut.

Sebagai tambahan pandangan dari perspektif pihak pemutaran, Kinoki bekerja sama dengan ruang pemutaran alternatif lain, yakni Kineforum Dewan Kesenian Jakarta. Mereka bekerja sama dalam menentukan klasifikasi sebuah film, terutama film Indonesia, dengan tetap mempertimbangkan posisi penonton masing-masing. Seperti yang diterangkan Tamalagi bahwa melihat film secara keseluruhan dan meninjau secara berkala juga dilakukan di di Kineforum. Ia menambahkan, "Secara pribadi aku dan programmer Kineforum, Lisabona Rahman, berkawan. Secara politis searah. Maka kami biasanya diskusi untuk mengklasifikasi. Untuk Indonesia kami biasanya punya klasifikasi yang sama. Kecuali kasus film Babi Buta yang Ingin Terbang. Lisa tidak berani dengan kategori umur 21+, sedangkan aku berani. Dasarnya ya penonton, penonton kami berbeda.

Film adalah ekspresi dari pembuat film. Oleh karena itu dalam klasifikasi, pembuat film mempunyai hak dan kewajiban terkait penonton. Hak pembuat film adalah mempertontonkan karyanya sekaligus wajib melindungi penontonnya. Namun, Kinoki melihat sangat sedikit pembuat film yang menyiapkan batasan umur untuk penonton filmnya. Oleh karena itu, Kinoki mengambil alih pengklasifikasian film sepenuhnya. Apabila pembuat film sudah menyiapkan klasifikasi sendiri atau ingin berperan serta, Kinoki membuka diri untuk berdialog.
Pembuat film pun memiliki hak untuk menentukan batasan umur audiens mereka, tapi biasanya mereka belum persiapan. Contohnya saat pemutaran film At the Very Bottom of Everything karya Paul Agusta. Batasan umur yang disiapkan Kinoki adalah 21+, sementara pembuatnya meminta $17+$. Jika terjadi hal seperti itu, yang dilakukan Kinoki adalah berdialog. Kinoki mempertimbangkan bahwa tidak semua mahasiswa telah berumur 21 tahun, program akselerasi dan faktor lain dapat menjadi penyebabnya. Pertimbangan tersebut sesungguhnya penting dalam klasifikasi umur karena hal itu sudah luput dalam kebijakan sensor.

Posisi penerimaan penonton di Kinoki ditelaah berdasarkan beberapa hal. Pertama, karakteristik kota penonton. Domisili Kinoki di Yogyakarta, sehingga karakteristik penonton mengacu pada perkembangan masyarakat di Yogyakarta. Misalnya, dengan melihat tingkat pendidikan atau tingkat pendapatan warga setempat. Kedua, lebih melihat konteks penonton dari perkembangan usia biologis, bukan fisiologisnya. Usia biologis melihat pertumbuhan anak perempuan dari sudah atau belumnya mengalami menstruasi. Sedangkan usia fisiologis hanya melihat angka pada umur.

\section{Elemen dalam Pengklasifikasian Film}

Regulasi film, baik itu sistem sensor atau klasifikasi, seharusnya memiliki landasan yang kuat dalam menentukan sisi yang dinilai penting diperhatikan dalam penyensoran ataupun klasifikasi. Klasifikasi sebuah film di Kinoki dilandaskan pada pasal-pasal klasifikasi film hasil studi MFI, dengan tetap mempertimbangkan tingkat penerimaan penontonnya di daerah pemutaran.

Dengan melihat klasifikasi hasil studi MFI, terdapat dua elemen kerangka pemikiran yang dipertimbangkan dalam perumusannya. Dua elemen itu adalah umur dan segi-segi. 


\section{a. Umur}

Klasifikasi film MFI menghasilkan enam jenis penonton. Keenam klasifikasi penonton tersebut adalah Semua Umur, 12+, DO, 15+, 18+, dan 21+. Klasifikasi ditentukan oleh batasan umur dan koteks keterlibatan orang tua dalam mendampingi anak. Fenomena hukum Indonesia yang seringkali berbeda tentang pembatasan umur menyebabkan MFI ingin memperjelas apa yang harus dipertimbangkan dalam pembagian umur untuk klasifikasi. Dalam undang-undang perlindungan anak, definisi umur anak adalah 0-18, sedangkan di ranah lain 18 tahun sudah dianggap dewasa, sudah diperbolehkan ikut Pemilu, bahkan usia boleh menikah kurang dari 18 tahun. ${ }^{17}$

Menilik dari keadaan di Indonesia, klasifikasi umur tersebut mengacu pada pertumbuhan penonton dalam jenjang pendidikan. Penonton umur 12 tahun ke atas cenderung menempuh Sekolah Menengah Pertama, 15 tahun ke atas menempuh Sekolah Menengah Atas, sedangkan 18 tahun ke atas cenderung menempuh Perguruan Tinggi. Adanya acuan pada jenjang pendidikan adalah hal yang tepat mengingat perubahan jenjang pendidikan akan memberikan lingkungan, informasi, dan pengetahuan baru.

Pada penerapannya, Kinoki dapat menoleransi dengan mengurangi atau menambah satu tahun dalam sebuah klasifikasi, mengacu pada tingkat pendidikan penontonnya. Dalam konteks ini adalah penonton di Yogyakarta yang dikenal sebagai kota pelajar dengan banyaknya jumlah perguruan tinggi.

\section{b. Segi-segi}

Segi-segi yang dijadikan acuan dalam klasifikasi film hasil studi MFI dapat dilihat dengan jelas pada tiap klasifikasi umur. Segisegi utama sebagai bahan pertimbangan yaitu

\footnotetext{
17 "Proteksi dengan Klasifikasi" dalam Laporan Kegiatan Kinoki.
}

tema, bahasa, ketelanjangan, seks, kekerasan, teknik yang bisa ditiru, horor, dan narkoba. Penetapan segi ini jauh lebih spesifik dan rinci, dibandingkan dengan yang ada di regulasi sensor. Pada regulasi sensor, segi seperti ideologi dan agama tidak mendapat perhatian khusus.

Adanya penjelasan segi-segi yang spesifik menunjukkan bahwa klasifikasi dilakukan lebih transparan daripada sensor. Hal ini memperkecil masuknya kepentingan lain di luar perlindungan penonton, yaitu kepentingan politis atau komersil. Penjelasan ini membantu masyarakat, khususnya seperti orang tua, untuk melakukan klasifikasi sendiri terhadap film-film yang belum diklasifikasikan MFI..

Namun tentu saja masih terlihat beberapa hal yang rancu. Salah satunya pembahasan tema, tidak dijelaskan tema seperti apa yang sesuai dengan umur tertentu. Hal ini mengharuskan pihak pemutaran mengetahui dengan baik tema seperti apa yang bisa diterima penontonnya.

\section{Aplikasi Klasifikasi dalam Pemutaran}

Kinoki mencantumkan batasan umur penonton sebagai keterangan penting dalam publikasinya. Judul film, nama sutradara, tahun pembuatan, serta sinopsis film juga dijadikan penunjang penonton agar dapat mengetahui lebih jauh tentang film yang akan diputar, pantas diterima penonton tersebut atau tidak. Keterangan klasifikasi dapat ditemui di segala bentuk publikasi Kinoki yaitu website, blog, situs jejaring sosial, poster, ataupun flyer. Dalam beberapa pemutaran tertentu, keterangan klasifikasi dapat ditemui di tiket masuk.

Di setiap pemutaran, Kinoki tidak lagi mempertimbangkan batasan umur secara fisiologis, namun lebih ke umur biologis. Kinoki tidak melakukan pemeriksaan umur penonton seperti memeriksa Kartu Tanda Penduduk (KTP). Kinoki lebih melakukan pengawasan ketat, memperingatkan apabila 


\section{Gambar. 1}

Keterangan klasifikasi dalam salah satu tiket menonton Kinoki

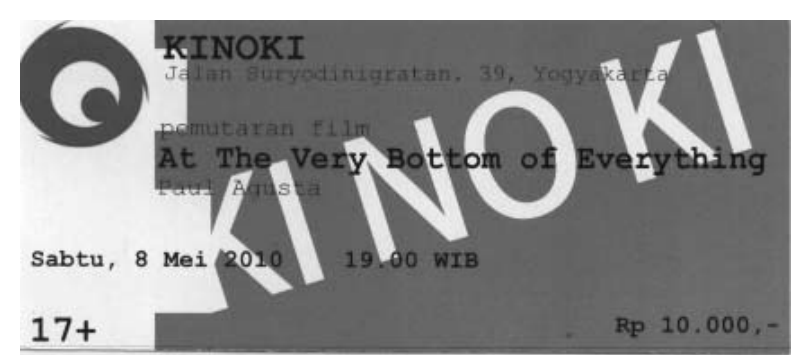

ada penonton yang terlihat kurang pantas menerima film yang akan diputar.

Dengan menerapkan sistem ini, Kinoki tidak menutup kemungkinan adanya penonton yang melanggar batasan umur secara fisiologis. Meski sistem ini ketat, namun sengaja tidak memberikan sanksi pada penonton. Melalui cara ini diharapkan kesadaran penonton tumbuh bukan karena aturan yang bersifat dogma, namun karena didukung oleh pengalaman dan kesadaran menonton..$^{18}$

Kinoki membuka seluas-luasnya ruang interaksi dengan penonton dalam berdialog mengenai konten film, agar sistem ini semakin memberikan dampak positif kepada penonton. Dalam beberapa pemutaran, diadakan acara khusus pembahasan atau diskusi antara pihak Kinoki, penonton, dan pembicara ahli jika kebetulan ada di Konoki, khususnya untuk program Kinology. Dialog pasca pemutaran ini juga diharapkan mampu mengurangi efek negatif dari film, bila ditonton oleh audiens di bawah batasan umur. ${ }^{19}$

Peneliti mengamati bahwa perbedaan ruang pemutaran alternatif, seperti Kinoki dan bioskop komersial, yang paling jelas adalah ada atau tidaknya dialog antara penonton dengan programer atau pihak pemutaran. Di bioskop saat ini tidak ada sistem yang memungkinkan untuk berdialog dengan penonton. Dalam hal ini tidak ada ruang sama sekali bagi penonton

\footnotetext{
${ }^{18}$ Wawancara dengan Elida Tamalagi.

${ }^{19} \mathrm{Ibid}$.
}

untuk melakukan complain mengenai substansi film.

Bila sistem klasifikasi film diterapkan secara luas, itu berarti akan ada pengurusan di bawah majelis atau badan klasifikasi. Majelis tersebut akan berfungsi sebagai perwakilan. Sistem perwakilan ini yang mungkin menjadi alternatif dari tidak adanya ruang dialog dengan penonton. Dialog akan berbentuk sistem perwakilan. Sedangkan untuk pengklasifikasian dalam skala kecil, seperti ruang pemutaran alternatif, harus ada perbedaan atau penyesuaian, misalnya lebih membuka dialog langsung pada individu penonton.

Ketika sistem klasifikasi diaplikasikan secara nasional, perlu dilakukan riset atau persiapan dalam kurun waktu yang panjang, serta pembuatan sistem hukum. Hal ini adalah alternatif dari tidak adanya ruang dialog di bioskop komersial secara langsung. Maka dialog yang muncul adalah praregulasi atau sebelum regulasi diterapkan. Sedangkan untuk membaca perubahan daya penerimaan penonton, regulasi itu perlu ditinjau dalam kurun waktu tertentu secara periodik.

\section{Penerimaan Publik}

Membaca penerimaan publik sama halnya dengan membaca penilaian secara umum, atas sistem klasifikasi film yang digunakan Kinoki. Untuk mencegah kerancuan kata publik dengan kelompok mayoritas di masyarakat, publik yang dimaksud di sini mengacu pada perspektif film sebagai karya seni atau ekspresi pembuatnya, serta film sebagai komunikasi massa. Sehingga publik dalam konteks ini adalah pihak yang terkait dalam setiap pemutaran secara langsung, yaitu penonton dan pembuat film.

Untuk mengkaji kesadaran penonton pada aturan pemutaran, penulis melakukan wawancara pada dua jenis penonton Kinoki yaitu penonton aktif dan pasif. Definisi dua jenis penonton ini mengacu kepada 
tingkat kesiapan menonton, bukan intensitas menonton. Pertama, penonton aktif. Yaitu penonton yang datang dengan kesiapan menonton. Penonton aktif biasanya telah mengakses informasi mengenai film yang akan ditonton. Sedangkan penonton pasif datang untuk menonton film tanpa persiapan sebelumnya.

Penonton pasif memiliki tingkat kesadaran yang rendah pada regulasi sebuah pemutaran. Terlebih jika mengingat bahwa penonton pasif belum mengetahui banyak informasi tentang Kinoki sebagai ruang pemutaran alternatif. Tyo, salah satu penonton memberikan keterangan, "Saya melihat Kinoki bagus karena memutar film independen yang gak ada di teater. Saya baru pertama kali datang dan menikmati saja. Tidak terlalu peduli dengan regulasinya." ${ }^{20}$

Ketidaksadaran pada aturan pemutaran secara tak langsung mematikan posisi sistem klasifikasi film sebagai panduan di Kinoki. Jangankan mencoba mengikuti klasifikasi umur sebuah pemutaran film, penonton pasif bahkan tidak mempedulikan adanya klasifikasi umur. Ketidakpedulian pada sistem aturan pemutaran bisa disebabkan karena penonton terbiasa dengan regulasi sensor. Dalam regulasi ini penonton menerima film yang sudah disensor oleh Lembaga Sensor Film. Penonton tidak perlu terlibat dalam mencari informasi tentang film.

Beberapa penonton pasif lain, sudah cukup menyimak adanya sistem klasifikasi di Kinoki, meski tidak mempedulikannya lebih jauh. Pada perspektif penonton yang memandang film sebagai estetika dan berbeda dengan kehidupan sehari-hari, regulasi film dianggap tidak penting.

Hal itu diungkapkan oleh Saiful, "Bagi saya baik sensor maupun klasifikasi seharusnya tidak ada, agar penonton menerima semua apa adanya. Biarkan penonton mencerna langsung, karena bagi saya film tidak akan berpengaruh

\footnotetext{
${ }^{20}$ Wawancara tanggal 10 Oktober 2010.
}

langsung. Adanya keterangan klasifikasi saya perhatikan di publikasi, tetapi sekadar sebagai keterangan, bukan berarti saya taati. ${ }^{21}$ Ketika penonton tidak menganggap film dapat menimbulkan pengaruh secara psikologis ataupun sosial pada dirinya, berarti penonton tersebut tidak membutuhkan perlindungan dalam menerima informasi.

Sedikit berbeda dengan penonton aktif. Kesadaran regulasi memang telah muncul namun bukan berarti mendukung sistem yang ada, baik sensor pemerintah ataupun klasifikasi Kinoki. Penonton aktif yang sebagian sudah mengakses informasi sebelum menonton menyebabkan penonton aktif lebih siap dalam melakukan self censorship.

Penonton aktif berpandangan bahwa regulasi sensor ataupun klasifikasi tidak harus ada, mengingat penonton bisa mencari informasi terlebih dahulu tentang film yang akan mereka tonton. Saat menonton adegan yang tidak pantas diterima, penonton pun punya pilihan untuk berhenti menonton.

Klasifikasi tidak diperlukan karena penonton seharusnya bisa menentukan film yang akan ditontonnya sendiri, dengan segala informasi yang ada. Misalnya membaca sinopsis. Berbeda dengan berita televisi yang memberikan informasi tiba-tiba dan apa adanya, sehingga memerlukan sensor seperti di Amerika, selama membaca atau mengetahui terlebih dahulu tentang film tersebut, penonton pasti siap. Kalaupun tidak siap, cara paling mudah contohnya dengan menutup mata jika ada adegan yang tidak ingin dilihat.

Penonton pun ada yang menganggap sistem klasifikasi bukanlah langkah yang baik. Hal itu terkait batasan umur atau rating. "Rating sendiri menurut saya di Amerika tidak berlangsung dengan baik. Kadang ada pengecekan umur tapi itu tidak ketat. Anak di bawah umur tetap bisa menonton dengan menunggu petugas jaga pergi. Rating justru bisa

${ }^{21}$ Wawancara tanggal 12 Oktober 2010. 
membuat ketertarikan penonton meningkat. Semakin kontroversial semakin ingin ditonton" ujar salah satu penonton, Gillian. ${ }^{22}$

Adanya rating dapat membuat penonton tertarik pada film yang tidak sesuai klasifikasi umurnya. Serupa dengan satu poin keputusan Mahkamah Konstitusi saat menolak penerapan sistem klasifikasi, sesuai tuntutan pihak-pihak perfilman dalam sidang pengujian regulasi sensor. Penolakan tersebut karena menilai sistem ini mempunyai kelemahan dalam praktik, yaitu kategorisasi "adults only" atau khusus dewasa justru akan mengundang minat kelompok umur yang belum dewasa, sehingga menjadi publikasi gratis untuk menarik keingintahuan anak-anak. ${ }^{23}$

Penulis tidak menemukan adanya penonton yang mencari film dengan rating dewasa (21+). Namun Tamalagi sempat membenarkan bahwa sistem klasifikasi berdampak dalam ketertarikan penonton. Mengenai akan adanya dampak yang tidak sesuai dengan penerapan sistem klasifikasi, beberapa penonton merasa hal itu mungkin terjadi. Tetapi adanya ruang komunikasi pasca pemutaran, antara pihak Kinoki dan penonton, bisa meluruskan dampak-dampak yang dianggap negatif tersebut.

Kinoki sangat membantu melihat peta film, menentukan poin-poin dalam program bulanannya, dan membantu menemukan komunitas untuk bertukar pikiran. Ada pula penonton, Tono, yang menganggap sistem klasifikasi bukan diterima sebagai sistem pemutaran melainkan hanya membantu calon penonton. "Di Kinoki saya tidak melihat adanya ruang sensor, karena bagaimanapun sebuah film adalah gagasan dari pembuatnya. Film harus diterima utuh. Klasifikasi sangat membantu memberikan pilihan pada penonton sebelum menonton, tapi penonton bebas

\footnotetext{
$\overline{22}$ Wawancara tanggal 10 Oktober 2010.

${ }^{23}$ Risalah Sidang Perkara Nomor 29/PUU-V/2007. Hlm. 17.
}

memilih. Poin pentingnya adalah selalu ada komunitas yang membuka diri, sehingga bisa mewacanakan lingkup kajian. Hal ini tidak bisa diterapkan ke bioskop karena tidak memiliki kedekatan" terangnya. ${ }^{24}$

Berdasarkan asumsi itu, llasifikasi menjadi boleh dilanggar selama ada bimbingan atau diskusi. Penonton lain, Bintang, juga berpendapat bahwa yang terpenting adalah adanya ruang dialog, antara pihak pemutaran sebagai programmer dengan penonton. Apabila ruang ini telah terwujud, sistem apapun tidak diperlukan lagi. ${ }^{25}$ Poin penting lainnya terkait klasifikasi diungkapkan oleh Dimas. ${ }^{26}$ Menurutnya, selain masalah kesadaran dan kebutuhan akan regulasi pemutaran, ditemui juga penonton yang sudah mulai memikirkan keberlangsungan aplikasi sistem tersebut. Sebagian penonton cenderung meminta klasifikasi, khususnya yang mengacu pada hal-hal yang bersifat pornografi.

Ketidaksadaran dan ketidakbutuhan penonton pada sistem klasifikasi menjadi dilematis. Sistem ini muncul dari perlindungan yang disiapkan Kinoki sebagai pihak pemutaran, namun tanpa adanya kebutuhan dari penonton sendiri. Definisi "penonton" yang dimaksud Kinoki menjadi tanda tanya.

Penonton dalam definisi Kitley (2000: 77-78) adalah suatu proyeksi, oleh suatu lembaga, atas keanekaragaman tanpa batas dari praktik-praktik menonton yang nyata dari individu-individu dan kelompok-kelompok. Lembaga perlu mengendalikan konstruksi penonton sebagai cara untuk mempertahankan kelangsungan hidup mereka. Senada dengan pendapat Saputro yang berpendapat bahwa, di tangan elit penguasa festival dan panitia aksi politik, penonton aktual-historis menjadi penanda kosong ("penonton") yang dibiarkan lepas mengapung-apung dalam lautan politik

\footnotetext{
${ }^{24}$ Wawancara tanggal pada 10 Oktober 2010.

${ }^{25}$ Wawancara tanggal 12 Oktober 2010.

${ }^{26}$ Wawancara tanggal 14 Oktober 2010.
} 
penandaan (Saputro, 2009: 177). "Penonton" hanyalah konstruksi normatif yang memberi legitimasi aksi politik tertentu.

Ada duajenis "penonton" di sini. Penonton lemah yang harus dilindungi dan penonton liar yang harus diawasi. Sejajar dengan pemikiran Siegel tentang rakyat dan massa (Siegel, 1998: 66). Keduanya merupakan proyeksi kelas menengah, tetapi memiliki fungsi yang berbeda. Rakyat meneguhkan fungsi kepemimpinan kelas menengah, sedangkan massa menjelmakan ketakutan kelas menengah. Keduanya bisa berubah dari satu menjadi yang lain sehingga hubungan ini tetap dalam keadaan ambigu, menegangkan, dan perlu terus-menerus dipantau dan dikendalikan.

Menanggapi penerimaan penonton ini, menurut Tamalagi, Kinoki menyadari jika belum dapat melihat dampak dari penerapan sistem klasifikasi secara signifikan. Tetapi Kinoki masih punya harapan pada sistem ini, oleh karena itu penerapan ini akan terus dilanjutkan sampai tahap untuk ditinjau ulang.

Dari pembahasan di atas, bukan berarti tidak ditemukan hal positif dari penerapan sistem klasifikasi di Kinoki. Dalam pembacaan penerimaan penonton, disinyalir bahwa penonton membutuhkan regulasi. Artinya bukan hanya sistem klasifikasi, namun sistem sensor yang selama ini berlaku di Indonesia. Protes untuk menyensor film di Indonesia selama ini kemungkinan muncul dari tipe penonton yang merepresentasikan lembaga, yang mengusung kepentingan ideologisnya. Contohnya adalah ormas-ormas yang mengatasnamakan Islam, yang kerap melakukan demonstrasi meminta larangan pemutaran film.

\section{Penerimaan Pembuat Film}

Kebebasan berekspresi yang terbatasi oleh sensor mengindikasikan bahwa film Indonesia terkekang untuk berdialog dengan kenyataan sosial masyarakatnya. Hal ini diamini oleh
Usmar Ismail. Dalam salah satu artikelnya, ia menulis tentang sensor sebagai berikut (dalam Nugroho, 1995: 143):

"Persoalannya adalah apakah seorang
sineas bebas memilih tema cerita
yang hendak difilmkannya, bebas
mengungkapkan cerita itu dengan
cara-cara yang efektif. Karena pada
hakikatnya perasaan dibatasi itulah
yang menyebabkan para pembuat film
Indonesia menjadi steril. Tiap kali dia
hendak menggugat suatu persoalan
kemasyarakatan, dia terperosok ke
dalam bermacam-macam lubang
perangkap, masuk ke dalam daerah-
daerah terlarang."

Ketidakbebasan mengangkat tema menjadikan fungsi film berwajah dua. Pelarian dari masalah-masalah sosialnya, menjadi propaganda dari yang disebut Asrul Sani "manusia-manusia tidak tersentuh". Dengan kata lain, film Indonesia hanya mengangkat manusia yang hidup dalam dunia normative, yakni manusia yang hanya hidup di satu sisi. Lebih parah lagi, tema dan tokoh-tokoh senantiasa dituntut untuk memberikan tuntunan moral, sehingga film sekadar menjadi propaganda tanpa perspektif (Nugroho, 1995:145).

Menelaah penerimaan pembuat film yang memutar karyanya di Kinoki, mayoritas tidak menyetujui adanya sensor. Ruang pemutaran alternatif seperti Kinoki sangat didukung karena memberi mereka kebebasan untuk mempertontonkan karyanya secara utuh. Selain itu ada pemrograman dan diskusi pasca pemutaran, sehingga wacana dalam film tersampaikan. Pembuat film juga bisa menerima umpan balik secara langsung dari penonton. Seperti yang tersirap dalam salah satu wawancara dengan pembuat film, Jobelle C. Catequista.

Menurutnya, pemutaran dalam ruang alternatif seperti Kinoki sangat bagus karena adanya kedekatan, terbangun komunitas, bukan sekadar festival yang glamor dan hanya 
berusaha menjual film. Di Filipina banyak film tentang kemiskinan tetapi pembuat film tidak punya kepedulian tentang kemiskinan itu sendiri. Akan lebih baik jika ada diskusi, ada program yang tematik, ada opini yang bisa diliat dari berbagai perspektif.

Di Filipina sendiri ada sensor yang kuat. Kekuatan terbagi dua antara gereja dan pemerintahan, tetapi gereja lebih kuat untuk urusan sensor. Film uncensored bisa dilihat hanya di tempat-tempat pendidikan seperti universitas, sehingga sangat sedikit yang akan menonton. Sebagai filmmaker, Catequista berpendapat bahwa cara klasifikasi lebih baik dibandingkan sensor, karena film baginya adalah sebuah gagasan, sebuah proses penyampaian pesan. Penonton harus menerima pesan tersebut secara utuh. Adanya klasifikasi membuat film dapat sampai tepat kepada target audiens. Salah satu masalah yang mungkin timbul dari klasifikasi adalah, pembuat film mempersiapkan karyanya untuk batasan umur $15+$, namun oleh badan klasifikasi ditetapkan menjadi 18+. Hal itu menyebabkan film akan kehilangan banyak audiens. ${ }^{27}$

Terkaithal tersebut, pembuat film cenderung tak memikirkan regulasi film dari perspektif penonton. Sensor dianggap mengganggu karena membatasi ekspresi, bukan dalam konteks menerima informasi. Mereka kebanyakan juga tidak memikirkan alternatif dari sensor. Sehubungan dengan pemutaran di Kinoki yang menggunakan sistem klasifikasi, pembuat film cenderung menyerahkan kebebasan klasifikasi kepada pihak Kinoki.

Pembuat film sebagian besar mendukung sistem klasifikasi karena alasan membenci sensor, bukan karena melihat sistem klasifikasi sebagai alternatif yang lebih baik. Ada dukungan bernuansa optimis pada sistem klasifikasi karena akan membuat penonton lebih tersegmen, namun ada juga ketakutan

${ }^{27}$ Wawancara dilakukan tanggal 25 Oktober 2010. Jobelle pernah melakukan pemutaran film karyanya berjudul Agpansula di Kinoki. bahwa sistem klasifikasi akan mengurangi jumlah target penontonnya.

\section{Simpulan}

Kebijakan pemutaran yang digunakan Kinoki berpusat pada upaya melindungi penonton dari informasi yang diterima. Tujuan utamanya justru bukan berkaitan dengan kebebasan berekspresi dari perspektif pembuat film ataupun membantu kepentingan pemerintah untuk menjaga identitas bangsa. Hal ini dilakukan Kinoki sebagai cara kritis untuk berpihak pada penonton dalam ruang yang nyata, sesuai konteks ruang dan waktu ketika pemutaran film dilangsungkan.

Ada beberapa hal yang diperhatikan dalam melakukan klasifikasi sebuah film. Pertama, sebagai pihak pemutaran Kinoki memegang tanggung jawab penuh terhadap penonton. Kedua, klasifikasi di Kinoki dilihat dalam konteks film secara keseluruhan, bukan adegan per adegan. Ketiga, adanya ruang terbuka untuk berdialog dengan filmmaker dalam mengklasifikasi. Keempat, klasifikasi sebuah film dilandaskan dengan mempelajari klasifikasi dari hasil studi MFI, dengan tetap mempertimbangkan tingkat penerimaan penonton.

Sistem klasifikasi Kinoki dalam penerapannya lebih merupakan tuntunan atau panduan, daripada aturan. Ini merupakan kebijakan untuk tidak menekan kemungkinan negosiasi yang berlainan dari tiap individu. Dalam pra pemutaran, Kinoki melakukan publikasi klasifikasi film yang akan diputar melalui beberapa media.

Dalam pemutarannya, Kinoki tidak melakukan pemeriksaan umur secara fisiologis seperti melihat KTP, tetapi lebih melakukan pemeriksaan umur biologis. Kinoki juga melakukan dialog sebagai upaya mengingatkan audiens apabila ada penonton yang tidak sesuai dengan sistem klasifikasi film. Dalam pasca pemutaran, Kinoki membuka ruang dialog untuk menekan adanya dampak negatif dari pemutaran film. 
Bagi penonton, ada kepedulian pada regulasi, namun bukan berarti penonton setuju dan menaati sistem klasifikasi yang ada sebagai panduan. Dari pembacaan penerimaan publik, ditemukan bahwa untuk menekan dampak negatif dari film, penonton justru membutuhkan adanya ruang-ruang dialog. Ruang dialog merupakan komunikasi penonton dengan pihak pemutaran, penonton dengan pembuat film, ataupun penonton dengan ahli wacana dalam film. Mengenai penerimaan pada sistem klasifikasi, pembuat film mendukung karena langkah ini dianggap tidak membatasi ekspresi, sehingga lebih baik dari regulasi sensor.

Dengan mengkaji penerimaan publik pada sistem klasifikasi film, dapat disimpulkan bahwa belum ada perhatian penuh dari penonton pada sistem ini. Kinoki sebagai ruang pemutaran alternatif, mengunggulkan adanya ruang interaksi atau dialog antara penonton dan programmer, untuk mengarahkan agar film mencapai tujuan positif sesuai definisi tiap individu. Sistem klasifikasi film adalah upaya terbaik untuk mendukung hal tersebut.

\section{Daftar Pustaka}

Arief, M. Sarief dkk. (1997). Permasalahan Sensor E Pertanggungjawaban Etika Produksi. Jakarta: Badan Pertimbangan Perfilman Nasional.

Biran, H. Misbach Yusran, DR. Taufik Abdullah, dan S.M. Ardan. (1993). Film Indonesia (Bagian I). Jakarta: Perum Percetakan Negara RI.

Budiardjo, Miriam. (1991). Dasar-dasar Ilmu Politik. Jakarta: Gramedia.

Dahl, Robert A. (2001). Perihal Demokrasi. Jakarta: Yayasan Obor Indonesia.

David, M., dan C.D. Sutton. (2004). Social Research: The Basics. London: Sage.

Irawanto, Budi. (1999). Film, Ideologi dan Militer. Yogyakarta: Penerbit Media Persada.

Irawanto, Budi, Novi Kurnia, dan Rahayu. (2004). Menguak Peta Perfilman Indonesia. Jakarta: Kementrian Budaya dan Pariwisata
Republik Indonesia, Jurusan Ilmu Komunikasi Universitas Gadjah Mada, Fakultas Film Televisi Institut Kesenian Jakarta.

Jowett, G. dan J Linton. (1980). Movies as Mass Communication. Beverly Hills: Sage.

Nawawi, Hadari. (1983). Metode Penelitian

Bidang Sosial. Yogyakarta: Gadjah Mada University.

Nugroho, Garin. (1995). Kekuasaan dan Hiburan. Yogyakarta: Yayasan Bentang Budaya.

Nugroho, Garin. (2005). Seni Merayu Massa. Jakarta: Penerbit Buku Kompas.

Saputro, Kurniawan Adi. (2005). “Melihat Ingatan Buatan: Menonton Penonton Film Indonesia 1900-1964". Penghibur(an). Yogyakarta: Penerbit Kanisius.

Siegel, James T. (1998). “Early Thoughts on The Violence of May 13 \& 14, 1998 in Jakarta". Indonesia. Cornell SEAP.

Turner, Graeme. (1991). Film as Social Practice. London: Routledge.

\section{Dokumen}

Kinoki. (2010). "Proteksi dengan klasifikasi" dalam Laporan Kegiatan Kinoki. Yogyakarta.

Kinoki. (2010). “SHOK” dalam Laporan Kegiatan Kinoki. Yogyakarta.

Kinoki. (2010). "Sinema Anak" dalam Laporan Kegiatan Kinoki. Yogyakarta.

Mahamah Konstitusi. (2007). Risalah Sidang Perkara Nomor 29/PUU-V/2007. Jakarta

\section{Internet}

Masyarakat Film Indonesia. Apa Permasalahan Mendasar Perfilman. (http:// masyarakatfilmindonesia.wordpress. com/2007/04/27/apa-permasalahanmendasar-perfilman/ diakses pada 1 Oktober 2010).

Masyarakat Film Indonesia. FAQ. (http:// masyarakatfilmindonesia.wordpress.com/ faq/ diakses pada 1 Oktober 2010). 